\title{
Things That are Near Though Distant: Extramarital Affairs in Heian-Period Japan
}

Matthew Grubits

University of Tasmania

\begin{abstract}
According to historian William McCullough, a society cannot be understood without an appreciation of its marriage institutions, for marriage institutions are a dominant strand in the fabric of any society. In the Heian period, however, there was an even more dominant strand in the fabric of society than marriage that impinged on the relationships between aristocratic men and women. As historian Ivan Morris points out, the most prevalent relationships between men and women were extramarital affairs. If an appreciation of marriage institutions is necessary for us to understand Heian society, then an appreciation of affairs is likewise necessary.
\end{abstract}

Few historians have addressed the subject of affairs, though they are central to the most notable texts from the period. This article addresses this gap in scholarship by exploring why affairs were so prevalent during the Heian period. This exploration involves looking at the marriage institution, perceptions of sexuality, belief systems and, importantly, aestheticism. Heian society was intensely aesthetic - a great emphasis was placed on pathos, beauty and aesthetic acts such as composing poetry. This paper argues that affairs were themselves aesthetic acts; that is, they were occasions of aesthetic expression. Because aristocrats had a preoccupation with aestheticism, they embraced affairs.

\section{Keywords}

Aesthetics, aristocrats, gender relations, Genji, Heian

\section{Introduction}

One of the three things the Heian-period lady-in-waiting Sei Shōnagon includes in her list of 'Things That are Near Though Distant' is 'Relations between a man and a woman.' William McCullough, a scholar of Heian-period Japan, argues an understanding of

1 Shōnagon, The Pillow Book, p. 181. 
relations between men and women is vital for the historian to appreciate any given society. He places particular emphasis on marriage institutions, for 'Marriage institutions constitute one of the dominant strands in the fabric of every human society, shaping the family, determining relationships among individuals...' ${ }^{\prime 2}$ There was, however, an even more dominant strand in the fabric of Heian society than marriage institutions. Ivan Morris writes in his well-known book The World of the Shining Prince, the 'numerically most frequent type of relations between men and women in Heian-kyō were those of a casual and promiscuous nature. ${ }^{3}$ If, as McCullough suggests, understanding marriage institutions is necessary to better understand Heian society, then so too is understanding casual and promiscuous relationships.

Few scholars of the Heian period have specifically studied extramarital relationships. Morris is perhaps the most explicit on the matter. It may seem his engagement with the subject was inevitable, given the strong links between Shining Prince and The Tale of Genji (Genji monogatari), to which extramarital relationships are central. Other scholars who have also engaged with Genji, however, have avoided the subject. While this could suggest historians are hesitant to place too much emphasis on extramarital relationships from prudery or a fear the Heian period will appear debauched, it is more likely historians have neglected the subject because the ubiquity of extramarital relationships has lessened their significance. Recently, historians have neared the topic by exploring gender roles, sexuality and morality. Noteworthy among these are Hitomi Tonomura and Janet Goodwin. ${ }^{4}$ It may be that discussions such as theirs were necessary before discussions on extramarital relationships could proceed.

This article addresses this gap in scholarship by exploring why extramarital relationships were so prevalent in the Heian period. It looks at marriage institutions, perceptions of sexuality, religion and, importantly, aestheticism. As shall be seen, all of these aspects of Heian life encouraged, facilitated and legitimised extramarital relationships. Hereafter, these relationships will be simply referred to as affairs, meaning extramarital, heterosexual, sexual relationships, not limited to adultery, but also including fornication and rape as they are commonly understood today. Like most discussions of the Heian period, this article only relates to aristocratic Heian society; to those people variously called the cultured people, the courtly people, the people of rank, and the good people.

\footnotetext{
McCullough, 'Japanese Marriage Institutions', p. 103.

Morris, The World of the Shining Prince, p. 225.

Tonomura, 'Black Hair and Red Trousers'; Goodwin, Selling Songs and Smiles.
} 
Much can be learnt about the aristocrats and their affairs from such wellknown works of Heian literature as the aforementioned Tale of Genji by Murasaki Shikibu, The Pillow Book (Makura no sōshi) by Sei Shōnagon, and The Gossamer Years (Kagerō nikki) by the Mother of Michitsuna. At the time these works were composed, affairs were a common part of everyday life. These works reveal an aristocratic man was generally free to enter an affair with any woman, heedless of her identity, age and marital status. While not impossible, it was less likely for a man to have a relationship with a woman above his own rank. Affairs involved people of all ages. When she is between thirty and forty years old, the Mother of Michitsuna discovers her father is still philandering when he announces the birth of another child. ${ }^{5}$ When only nineteen years old, Genji spends the night with the fifty-seven or fifty-eight year old Dame of Staff. ${ }^{6}$ Genji has numerous affairs; in addition to having sexual relations with his wife Aoi, Genji has sexual relations with his father's concubine Fujitsubo, a married woman Utsusemi, and, among others, a woman whose identity he does not even know, Oborozukiyo. A man could have as many lovers as he could manage, be they women he visited at their residence, or installed in his own residence. Affairs could last for a single night or many years.

\section{Marriage}

The nature of Heian marriage institutions has been extensively discussed, most notably by McCullough. Marriages were polygynous and matrilocal, and were arranged for economic, political and practical reasons. Both McCullough and Tonomura tell us marriage was merely a social process that was neither sanctioned nor confirmed by law, Buddhism or Shinto. ${ }^{7}$ Divorce was similarly a social, non legal process; it was effected by no formal procedure, but was simply a matter of ending relations. ${ }^{8}$

An aristocrat was usually first married at puberty to someone of a similar age; of the pair, the girl was usually older than the boy. ${ }^{9}$ If a man took subsequent wives, his first wife would remain the principal wife and have precedence over the subsequent wives. ${ }^{10}$ While a man's first wife was usually chosen for him by his parents, he was generally free to choose his subsequent wives. A man may have taken a second wife out of love or if his first wife failed to have children. ${ }^{11}$

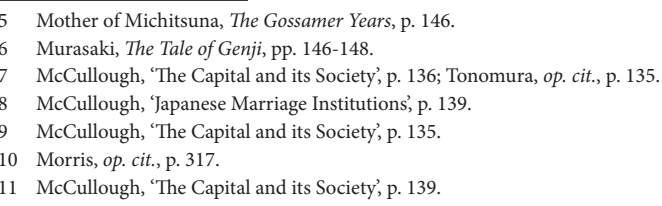


Upon marriage, a boy would usually move in with his wife and her parents. By moving into their house, a boy became reliant on his parents-in-law for economic support. Indeed, only upon their death might he be required to provide for himself and his wife. ${ }^{12} \mathrm{~A}$ boy relied on his father-in-law, rather than his own father, for political success. ${ }^{13} \mathrm{~A}$ man who had many daughters, then, was in a better position than a man who had many sons, for while sons would eventually leave him and rely on other men for support, he could carefully select husbands for his daughters whom he could influence and use to gain a political advantage for himself. While it was impossible for an aristocrat's son to ever become an emperor, there was always the possibility that his daughter could become an imperial consort and even the mother of an emperor. ${ }^{14}$

Matrilocal habitation may have been common because many marriages occurred between children who were incapable of running their own household. ${ }^{15}$ Older couples may have practised neolocal marriage, depending on their circumstances and the availability of space in the bride's family home. ${ }^{16}$ Neolocal arrangements in which the man provided the house were often associated with romantic love, for only love could attract a man to a woman who could not provide him with a house or any political or economic advantage. ${ }^{17}$ In some circumstances a couple had neither a matrilocal nor neolocal marriage; instead, they lived separately with the husband visiting the wife.

Even when husband and wife did live in the same house, they might not have cohabited in the same pavilion. This meant that husbands and wives, whether they lived together or apart, were not necessarily in close contact with one another. Although a husband could meet with his wife face-to-face without any obstructing screens, faceto-face meetings were unnecessary for communication. If not more convenient, it was certainly more aesthetic for a husband and wife to communicate via notes and poems. But even when in communication, there was every opportunity for both parties to live in relative independence. A husband could easily avoid the eyes of his wife while visiting and receiving whomever he pleased. While, then, it may not have been the case in the majority of households, there was the very real possibility that a husband and wife could be little more than acquaintances. Because of this physical distance and the ease with which couples could avoid one another, I would argue Heian marriage institutions did not foster loving relationships and thereby encouraged affairs.

\footnotetext{
12 Hurst, 'Kugyō and Zuryō', p. 72.

13 McCullough, 'Japanese Marriage Institutions', pp. 126-127.

14 Morris, op. cit., p. 207. Fujiwara no Michinaga, the son of Fujiwara no Kaneie by a wife other than the Mother of Michitsuna, certainly proved the value

of daughters. Michinaga was able to gain authority through marrying his daughters to important men; see Sanae and Watanabe, 'From Female Sovereign', pp.

30-32, and Hurst, op. cit., pp. 70-71.

15 McCullough, 'Japanese Marriage Institutions', p. 117.

16 Ibid.

17 Ibid., pp. 114-115; McCullough, 'The Capital and its Society', p. 138.
} 
Something of this can be seen in the marriage of Genji and Aoi. Genji is twelve years old and Aoi sixteen at the time of their marriage. Aoi, though she, like everyone, finds Genji extremely attractive, is embarrassed to be linked to someone so young. Genji, meanwhile, dreams only of Fujitsubo, his father's concubine, who reminds him of his dead mother. Because he is required to serve there, Genji more frequently resides at the palace than he does with his new wife. ${ }^{18}$ This physical distance, combined with Genji's preoccupation with Fujitsubo, creates an instant divide between the newlyweds that never truly closes. Although they have sexual relations, Genji is more interested in other women, and this annoys Aoi. Following her death at the age of twenty-six, Genji 'wondered in vain regret why she had taken such offence at each of his casual diversions, undertaken while he complacently assumed that she would eventually change her mind about him, and why she had persisted to the end in disliking him so.' ${ }^{19}$

As Haruo Shirane suggests, only outside marriage does Genji find true love. ${ }^{20}$ While his marriage to Aoi is unfulfilling, and even confusing, Genji finds satisfaction in extramarital affairs. Affairs, rather than marriage, cater to his aesthetic interests in romance, beauty and poetry. ${ }^{21}$ Shirane also points out that, unlike in Genji's extramarital relationships, not a single poem passes between Genji and Aoi, illustrating the absence of love and aestheticism in marriage. ${ }^{22}$ Marriage, this suggests, contributed to the prevalence of affairs by failing to be aesthetic and romantic outlets for aristocrats.

Shōnagon includes in her list of 'Depressing Things':

With much bustle and excitement a young man has moved into the house of a certain family as the daughter's husband. One day he fails to come home, and it turns out that some high-ranking Court lady has taken him as her lover. How depressing! "Will he eventually tire of the woman and come back to us?" his wife's family wonder ruefully. ${ }^{23}$

Like Genji, this young man feels no particular loyalty to his wife and, therefore, has no apparent qualms about becoming the lover of the high-ranking court lady. As the court was the centre of cultural expression, a court lady would hold far more appeal to the aesthete than would a woman who was somewhat removed from the court. A court lady could also potentially offer more political advantage. It is noteworthy that Shōnagon does not write of the young man's actions 'how inappropriate' or 'how

\footnotetext{
18 Murasaki, The Tale of Genji, p. 17.

19 Ibid., p. 178.

20 Shirane, 'The Uji Chapters', p. 117.

21 Ibid., p. 118.

22 Ibid., p. 117

23 Shōnagon, op. cit., p. 41
} 
infuriating' but rather 'how depressing'. His actions can hardly be condemned, for he has the freedom to come and go from his matrimonial home as he pleases and become romantically involved with women other than his wife. This further illustrates that marriage promoted affairs by not fostering love and not precluding either partner from seeking love elsewhere.

Marriage institutions may also have encouraged affairs in other ways. The newlywed boy and girl may have felt uncomfortable initiating sexual relations, either upon marriage or upon sexual maturation. It may have been more comfortable for a young man to enter a sexual relationship with someone other than the bride with whom he had grown up, and beyond the prying eyes of his parents-in-law. It is also possible love did not develop between many newlyweds, causing one party, or both, to look outside marriage for a fulfilling relationship.

\section{Sexuality}

Perceptions of sexuality allowed men and women to engage in extramarital affairs. Tonomura tells us sexual gratification, for both men and women in Heian Japan, was understood to be dependent on the presence of a male body; that is, a woman could only obtain sexual gratification through intercourse with a male, whereas a male, possessing a male body, could legitimately obtain gratification in a number of ways, from pederasty to masturbation. ${ }^{24} \mathrm{Men}$, due to the very nature of their physical composition, were afforded a greater range of sexual experiences than women, while women were made reliant upon men.

Male desire was considered innate and uncontrollable. ${ }^{25}$ This, Goodwin suggests, meant men could not be blamed for sexual misdemeanours, for they were driven by a natural force over which they had no power. ${ }^{26}$ Because they were perceived to be incapable of resisting desire, men could not be criticised for sexual acts we would not hesitate to call deviant today, such as rape; the uncontrollable nature of desire gave men permission to satisfy their lusts even in an unwilling female. ${ }^{27}$ Any violation that occurred was the result of passion, and if anyone was to blame, it was the female for letting her guard down. ${ }^{28}$ Women were further responsible for unsolicited propositions because, while they may not have actively encouraged any propositions,

\footnotetext{
24 Tonomura, op. cit., p. 148

25 Ibid.

26 Goodwin, op. cit., p. 55

7 Tonomura, op. cit., p. 151

28 Ibid., pp. 149-151.
} 
women were, by their very nature, enticing objects to men. ${ }^{29}$ Women were, by nature, irresistible, while men were, by nature, unable to resist.

While it was the responsibility of women to resist violation, a woman was also expected to be a passive recipient of sexual advances and any ensuing sexual activity. Assertive sexual behaviour on the part of a woman was considered unnatural and dangerous to both men and to herself. ${ }^{30} \mathrm{~A}$ woman who was not submissive could be accused of being a fox, or a tengu in female form, for, through not submitting, she did not conform to what was perceived to be normal. ${ }^{31}$

To further complicate the matter, a sexually inactive woman could also be considered to be abnormal. Morris writes, 'virgins were unusual in well-born families ... it was firmly believed that any girl who remained virgin for long had been possessed by an evil spirit. ${ }^{32}$ While people believed in possession, transforming foxes and tengu, it is unclear how often people were accused of being unhuman due to sexual apathy. If frequently, then people everywhere would surely have made certain they were seen to have a lover from fear of condemnation. The primary literature, however, does not suggest this was so. Indeed, in The Tale of Genji, rather than condemning the sisters at Uji for their chastity, friends Kaoru and Niou take a great interest in them. ${ }^{33}$ While, then, women may not have engaged in affairs merely from fear of being considered unhuman, superstition did encourage the view that the average woman participated in affairs.

The Heian woman, then, was not to be actively seductive, yet she was expected to be sexually active; she was supposed to prevent unwanted sexual encounters, yet she was also supposed to be submissive to men. While this, in theory, seems contradictory, Murasaki depicts women as having a less complex, less prescriptive approach to sexuality. Men, it would seem, did not begrudge women who were either reticent or outgoing:

Her Majesty frowns on the slightest hint of seductive behaviour as being the height of frivolity, so anyone who wants to be thought well of takes care never to seem too forward. Of course that is not to say we do not have women among us of quite a different persuasion, women who care nothing for being thought flirtatious and light-hearted and getting a bad name for themselves. The men strike up relationships with this kind of woman because they are such easy game. ${ }^{34}$

29 Goodwin, op. cit., pp. 55-56.

30 Tonomura, op. cit., pp. 146-147.

1 Ibid., p. 147. A tengu was an ugly, supernatural being. Foxes were also considered supernatural. Both could take the form of a person or possess a person.

32 Morris, op. cit., p. 213.

33 Murasaki, The Tale of Genji, p. 849-867.

34 Murasaki, Diary, pp. 50-51. 


\section{Religion}

Buddhism and Shinto both contributed to Heian views of sexuality and morality, and both, in different ways, supported extramarital affairs. The Heian aristocrat, however, seems to have had little real interest in religious doctrine. Edward Seidensticker writes of the aristocrat:

Good taste was his religion, and he was not given to speculative thought. This is not to say that he had no use for revealed religion; rather that he was not much worried about putting the universe in order, that religious notions and ceremonies but served to intensify the sweet sad beauty of the moment... ${ }^{35}$

The aristocrat was no religious zealot or fundamentalist; rather, in the Japanese tradition, aristocrats appropriated those parts of Buddhism and Shinto that supported their aesthetic lifestyle and world view. The Heian aristocrat was more interested in sentimentality and taste than spiritual speculation. ${ }^{36}$

In opposition to this view, one might argue that the frequently aired wish of the Heian aristocrat to retreat into monasticism demonstrates real spiritual fervour. It was, however, conventional for aristocrats to express a desire to retreat into monasticism; they were surely all too aware of the realities of monasticism and, therefore, thankful for any obstacles that prevented them retiring from the cultured life of the capital. ${ }^{37}$ The Mother of Michitsuna expresses as much when she writes, 'The priest ... was at the bank to say good-by, a sad expression on his face. It occurred to me that it would hardly be pleasant to stay on year after year in this temple, familiar to the point of boredom.'38 People spoke of renouncing the world because it was fashionable and appropriate to do so. Ultimately, if the many people who expressed a wish to retreat into monasticism were genuine, they would have rejected those transitory things that prevented a retreat and acted upon their wishes immediately.

In The Gossamer Years, there is an incident in which the children of a banished Minister of the Left are forced to become priests. ${ }^{39}$ The Minister himself becomes a priest, but his position is not recognised and he is made Governor-General of Kyushu instead, an apparently shameful position. ${ }^{40}$ This would suggest becoming a priest was both a way of escaping society and akin to punishment. By becoming a priest one was

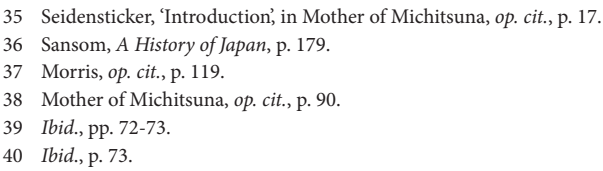


physically removed from Heian-kyō and the esteemed lifestyle it alone could offer. Anybody away from the city, be they in a distant province or in a monastery, was not interacting with elegant aesthetes and, therefore, in danger of becoming uncultured. If such was used as punishment for aristocratic transgressors, retreating into monasticism, though frequently spoken of, was surely not something most aristocrats truly wanted.

Heedless of whether or not the aristocrats were devout, Buddhism and Shinto still legitimised their affairs. Interestingly, though, the greatest difference between Buddhism and Shinto lay in their attitudes towards sexuality. ${ }^{41}$ Whereas Buddhism saw sex as a cause for continual rebirth into the terrestrial world, Shinto saw sex as something creative and productive. ${ }^{42}$ Shinto, then, by its very nature, saw affairs as positive acts. Of Shinto and Buddhism, though, Buddhism was more important to the aristocrats. ${ }^{43}$

Under Buddhism there was no concept of sin as under Christianity. Not wholly dissimilar to the Christian understanding of sin, though, was the Buddhist understanding of desires, which were illusions and obstructions to Buddhahood. ${ }^{44}$ With no concept of sin, there was no absolute right and wrong, merely behaviour that was beneficial and behaviour that was detrimental. Violation of a woman, then, was not inherently wicked, but a potential obstruction to a man obtaining Buddhahood. Violation, though, was no more a potential obstruction than any act born of desire. Matrimonial intercourse, equally a product of desire, was likewise an obstruction to Buddhahood. If even matrimonial intercourse could be disadvantageous, then rape, fornication and adultery were no less terrible deeds. All sexual activity, because it was caused by desire, was equal in its detriment and cause for suffering and rebirth.

Buddhism, though, for all its emphasis on shunning desire, could hardly condemn sexual activity outright, or else its followers would die out and with them the possibility of rebirth into a human form. Buddhism, then, conceded the inevitability of sexuality, and did not discourage sexual intercourse, only the desire for it. ${ }^{45}$ If all sexual activity was equal, and one form of sexual activity was allowed, then all forms of sexual activity were legitimised. Buddhism, then, can also be seen to support affairs, even while it viewed affairs as causes for suffering because of their links to desire. Buddhism may also have encouraged Heian-period aristocrats to view affairs in a similar way to the Kamakura-period Retired Emperor GoFukakusa: 'After thinking about the subject at great length, I have concluded that there is nothing sinful in the

\footnotetext{
41 Tonomura, op. cit., p. 134.

42 Ibid.

43 Morris, op. cit., p. 94.

44 Goodwin, op. cit., p. 7

45 Walshe, Buddhism and Sex, pp. 7, 19.
} 
relationships between men and woman inasmuch as they are usually caused by bonds from former lives and thus defy our resistance. ${ }^{36}$

\section{Aestheticism}

In his introduction to The Gossamer Years, Seidensticker writes, 'Perhaps the most striking feature of aristocratic Heian life, however, is its emphasis on good taste. Inaction, a word which seems to describe the tone of Heian life better than "effeminacy," gave rise to a vast and minute cultivation of taste and form. ${ }^{37}$ This 'cultivation of taste and form', which Morris calls the 'cult of beauty' and which I will simply call Heian aestheticism, bordered on the obsessive. The aristocrat strived to express beauty at every available opportunity. This preoccupation with beauty greatly contributed to the self consciousness of Heian society. Aristocrats were always on their guard lest they should appear ugly, graceless, apathetic or artless. Those who did exhibit these unfortunate characteristics became the subjects of mockery and gossip, and suffered severe embarrassment and humiliation.

The most obvious forms of aesthetic expression in Heian narratives are clothing and poetry. Liza Dalby points out that both clothing and poetry were means by which the aristocrat could demonstrate his or her sensibility and sensitivity. ${ }^{48}$ The aristocrat did so through complimenting the colours of their clothing with the season, by making appropriate, imaginative and novel allusions in poetry, and by always exhibiting personal flair within the narrow parameters of propriety.

In her diary (Murasaki Shikibu nikki), Murasaki writes:

I observed the ladies as they passed ... Those to whom the colours were forbidden, especially the older ones among them, had been careful to avoid anything out of the ordinary and had dressed simply in beautiful robes of three or four layers ... Now, as they looked at each other, they suddenly realised how, although each one of them had tried to show some originality, those of a common age are bound to have common tastes. There was a strong atmosphere of rivalry. ${ }^{49}$

There was a precise art to matching one's robes in both an appropriate and attractive way. Everyone, however, was not equal in skill, as Murasaki reveals:

\footnotetext{
46 Nijō, Confessions, p. 130.

47 Seidensticker, op. cit., p. 17.

48 Dalby, Kimono, p. 249.

49 Murasaki, Diary, p. 15. Certain colours were forbidden to certain ranks. Dress, therefore, revealed rank.
} 
...all the women had done their utmost to dress well, but, as luck would have it, two of them showed a want of taste when it came to the colour combinations at their sleeves, and as they served the food they came into full view of the nobles and senior courtiers. Later, it seemed that Lady Saishō and the others had been mortified; but it was not such a terrible mistake - it was just that the combinations were rather uninspiring ... The slightest mistake in a formal setting should indeed be the subject of censure... ${ }^{50}$

While men took no less care than women in matters of dress, dress was particularly important to women because, generally, their clothing was all men saw of them. When in the company of men, women were usually hidden behind screens. A woman could display a part of her sleeve or the hem of her costume beneath her screens to reveal her presence and the colour combinations of her robes. When travelling, a woman could display the combinations of her robes by wearing her sleeve outside her carriage. ${ }^{51}$ The colours of a woman's outfit revealed her nature and level of taste. Because women's faces were hidden, men assessed women by their costume, and even fell in love with women by glimpsing a sleeve or hem.

Like clothing, handwriting also revealed a woman's character and, like her clothing, could inspire love. Handwriting, more than speech, revealed a woman's character and breeding. ${ }^{52} \mathrm{~A}$ woman's reply to a poem, then, was one way a gallant could confirm the nature of a woman whose sleeve he had glimpsed. Poems and letters were ubiquitous in Heian Japan; they pervaded every aspect of Heian life. Every aristocrat was a poet to some degree. Poetry competitions were held, poetry anthologies were created, everyday conversation held allusions to poetry.

At the foundation of Heian aestheticism was a melancholy outlook. In Heian narratives, men and women frequently refer to wet sleeves, indicative of tears they have shed and wiped away. Weeping was accepted and even considered admirable, because it demonstrated emotional sensitivity. The ability to be moved by appropriate things, frequently transient things such as meetings, blossoms, autumn leaves and snow, was central to courtly refinement..$^{53}$ This melancholic, emotional outlook was encouraged by the nature of Buddhism, but Buddhism cannot be considered the sole progenitor of every aspect of Heian aestheticism, for there was also a brighter, more cheerful side to it. Processions, even dress, reveal a love for pomp and ostentatious display, and the Heian aristocrat was equally as capable of witty conversation as he or she was of lapsing into a depression.

\footnotetext{
50 Ibid., p. 65.

51 For a discussion on this practice, see Dalby, op. cit., pp. 247-248.

52 Sansom, op. cit., p. 186.

53 Varley, Japanese Culture, pp. 60-61.
} 
George Sansom suggests aestheticism roused stronger emotions in aristocrats than did their affairs. ${ }^{54}$ I would suggest aestheticism and affairs can not be separated from one another, and that affairs were actually a form of aesthetic expression. The aristocrat's occupation with aestheticism was not distinct from an interest in affairs, but incorporated an interest in affairs. This link, I would suggest, helps us understand why the aristocrats embraced affairs; affairs, being aesthetic acts, appealed to aristocrats as much as did the writing of poetry or the connoisseurship of robes.

\section{The Aesthetic Affair}

Morris argues that the rule of taste prevented affairs from 'degenerating into something crass and sordid. ${ }^{55}$ An affair, he writes, was, 'from beginning to end conducted according to an elegant ritual, with a strong aesthetic sense of how things should be done. ${ }^{56}$ Paul Varley agrees: 'the typical love affair was conducted according to exacting dictates of taste. ${ }^{57}$ This ritualisation and association with aestheticism, I would suggest, makes affairs aesthetic acts in themselves, as much so as the writing of poetry, and, therefore, appealing to the aesthetically-minded aristocrat.

Poems and letters played a particularly important role in the conduct of an affair. The Gossamer Years provides two examples of men using correspondence to proposition a woman. Michitsuna, perhaps after admiring her sleeve hanging from her carriage, enters correspondence with the mysterious 'lady from Yamato. ${ }^{58}$ The lady refuses to be wooed. Michitsuna's uncle, the Kami, begins a much more formal correspondence with the author regarding her adopted daughter. ${ }^{59}$ The Kami, most likely with thoughts of marriage, first asks the Mother of Michitsuna if he might begin seeing her adopted daughter. This shows the ritual that preceded relationships, the use of aesthetic expression in courting, and also the limited power aestheticism afforded women. Providing a man adhered to the aesthetic convention of approaching a woman through poetry and letters, a woman had the power to either discourage or encourage the advances of her suitor. Given Heian perceptions of sexuality, however, her power could be easily overridden.

Shōnagon writes of letters playing a role in the course of an affair. On at least two occasions she mentions the next-morning letter, which it was customary for a

\footnotetext{
54 Sansom, op. cit., p. 192.

55 Morris, op. cit., p. 227

56 Ibid., pp. 227-228.

57 Varley, op. cit., p. 65.

58 Mother of Michitsuna, op. cit., p. 136.

59 Ibid., p. 148-150.
} 
man to send his lover upon leaving her after a night of passion. In 'A Young Bachelor' Shōnagon paints a romantic picture of a young man returning home and taking great care in the composition and delivery of his next-morning letter. ${ }^{60} \mathrm{~A}$ reply returns while the young man is reciting the sixth scroll of the Lotus Sutra and, such is his affection for his lady, he immediately returns his attention to her. In 'On One Occasion a Man' Shōnagon describes a far less romantic experience in which a man, 'who invariably sent me a letter after we had spent the night together, declared that he saw no point in our relationship and that he had nothing more to say to me. ${ }^{61}$ The relationship between the Mother of Michitsuna and Fujiwara no Kaneie is ended with an exchange of poems. ${ }^{62}$

Interestingly, poetry, like affairs themselves, could be seen as contradictory to Buddhist principles. ${ }^{63}$ Poems, because of their content, could be regarded as frivolous and untrue and, therefore, detrimental to one's spiritual wellbeing. ${ }^{64}$ Poems, however, as has been mentioned already, were not only accepted by Heian society, but were as pervasive as were affairs. I would suggest there is a similarity in the way Heian society embraced poetry and the way it embraced affairs. I would also suggest poems and affairs fed off one another. Poems initiated affairs, and affairs initiated poems; poems and affairs were inseparable. This association with poetry strengthens the view that affairs were aesthetic acts. Poems, clearly aesthetic products, imbued affairs with a positive, aesthetic nature.

It has also been mentioned already that the Heian aristocrat frequently expressed the act of weeping by reference to damp sleeves. This is an example of clothing being used, without reference to colour combinations, to express aestheticism, specifically sensitivity. Liza Dalby writes, 'Romantic relations between men and women could not help but be influenced by the voluminous envelopes of clothing worn by the beau monde. Romance was expressed through poetic convention in images of tear-damp sleeves and spread-out robes.'65 This, I suggest, is another example of affairs being linked to a conventional form of aesthetic expression, namely dress.

Aestheticism was not only present in affairs materially, it was also present ideologically. Aestheticism determined how affairs were conducted through propriety. Shōnagon suggests on a number of occasions that there was a right and a wrong way to conduct a relationship. She writes, for example:

\footnotetext{
60 Shōnagon, op. cit., pp. 257-258.

61 Ibid., p. 239.

62 Mother of Michitsuna, op. cit., p. 145

63 Pandey, 'Poetry, Sex and Salvation', p. 62.

64 Ibid., p. 62.

65 Dalby, op. cit., p. 244.
} 


\begin{abstract}
A lover who is leaving at dawn announces that he has to find his fan and his paper ... Finally he discovers the objects. He thrusts the paper into the breast of his robe with a great rustling sound; then he snaps open his fan and busily fans away with it. Only now is he ready to take his leave. What charmless behaviour! "Hateful" is an understatement ... A good lover will behave as elegantly at dawn as at any other time. He drags himself out of bed with a look of dismay on his face ... he comes close to the lady and whispers whatever was left unsaid during the night ... Presently he raises the lattice, and the two lovers stand together by the side door while he tells her how he dreads the coming day, which will keep them apart; then he slips away. The lady watches him go, and this moment of parting will remain among her most charming memories. ${ }^{66}$
\end{abstract}

Shōnagon concludes, 'one's attachment to a man depends largely on the elegance of his leave taking. ${ }^{67}$ By using words such as 'charmless', 'elegantly' and 'charming', Shōnagon not only describes the affair as an aesthetic act, but she makes the description of the affair an aesthetic product in itself, demonstrating the mutuality between affairs and other aesthetic acts. Because the properly conducted affair, as described by Shōnagon, is a thing of beauty, it is, by nature, aesthetic.

Morris suggests, 'the cult of beauty prevented things from lapsing into mere crassness.68 It did not do so, however, by preventing crass behaviour, but by turning crass behaviour into beautiful behaviour. I would argue that, being aesthetic acts, affairs were not only an inseparable part of the cult of beauty, but were contributors to and continuers of the cult of beauty. Affairs were simultaneously products and producers of aestheticism. The aristocracy was preoccupied with aestheticism, affairs were aesthetic acts, therefore the aristocracy accepted affairs.

\title{
The Unaesthetic Affair
}

When void of aesthetic associations, affairs were in danger of becoming repugnant. The relationship between Kashiwagi and Onna San no Miya in The Tale of Genji is an example of an unaesthetic affair, that is, an affair that has few, if any, aesthetic associations and does not conform to aesthetic conventions.

Kashiwagi falls desperately in love with Onna San no Miya, a princess in Genji's care, and cannot resist making her his own:

\footnotetext{
66 Shōnagon, op. cit., p. 49. 
Her Highness had innocently retired to sleep when she detected a man nearby and assumed that it was Genji, but then the man lifted her deferentially down from the bed, and she felt oppressed as though by a bad dream. At last she peered up at him and saw that he was someone else ... she seemed to him very sweet and dear. ${ }^{69}$

Though Onna San no Miya calls out, no one hears her. Kashiwagi tries to persuade her to submit to him, saying, 'it is not as though this sort of thing has never happened before, and if it is your wish to be so astonishingly cruel, then I shall be very deeply hurt, and blind passion may master me after all. ${ }^{70}$ During the night, Kashiwagi rapes Onna San no Miya. By morning, his railing and her reticence cause both to resent the other. Kashiwagi, disappointed though his desire is assuaged, comes to regret his behaviour and recognises it as abominable, even as a crime, though not in any legal sense of the word. He neglects his wife (who is Onna San no Miya's sister) and lapses into a depression; this causes his wife to also lapse into a depression. Eventually he goes off his food and dies of starvation. Onna San no Miya, meanwhile, is plagued with shame and eventually gives birth to Kashiwagi's child, the aforementioned Kaoru.

Kashiwagi, not bound to be loyal to his wife, has the liberty to love, and lust after, other women. Because rape as we know it was sanctioned, his violating of Onna San no Miya is not a criminal act. Onna San no Miya feels guilt because she is enticing by nature and, while she is required to submit to those men who cannot, like Kashiwagi, refuse her, she is also accountable for her own violation. Ultimately, Onna San no Miya should never have allowed herself to be seen, for, in revealing herself, she ran the risk of rousing the natural passions of men.

I would suggest that, while not criminal in the Heian period, affairs of the sort just described were rendered improper due to a lack of accompanying aestheticism. In this example, Kashiwagi fails to approach Onna San no Miya in the appropriate way before entering a relationship with her and he does not behave appropriately afterwards according to prevailing aesthetic standards. What occurs, as a result, is regretful, depressing and chaotic.

Half of Shōnagon's list of 'Shameful Things' is devoted to problems stemming from the inappropriately conducted affair. She writes it is shameful for a man to mislead a woman, to be insincere, to be heartless and to abandon a woman he has impregnated. ${ }^{71}$ That such behaviour should be called 'shameful' is significant, for shame was the very

\footnotetext{
69 Murasaki, The Tale of Genji, pp. 650-651.

70 Ibid., p. 651.

71 Shōnagon, op. cit., pp. 144-145.
} 
thing every aristocrat avoided. Nobody wanted to be judged negatively, considered inadequate, or excluded for a perceived shortcoming.

I observe, then, three things about aestheticism. First, aestheticism created parameters for behaviour; that is, it determined how people did and did not act. While aestheticism did not explicitly prohibit behaviour such as Kashiwagi's, it did cause such behaviour to be viewed negatively. By causing certain behaviour to be viewed negatively, aestheticism implicitly promoted certain modes of behaviour. Second, aestheticism threatened penalties to those who did not act within aesthetic parameters. The penalties were not corporeal or capital punishment, but shame, embarrassment, mockery and gossip. Aestheticism caused people to be extremely self-conscious and, if not competitive, then at least comparative, as can be seen in the extracts from Murasaki's diary regarding clothing. People who did not conform or adhere to the prevailing aesthetic, who did not exhibit taste and pathos, opened themselves to criticism or ridicule by their peers. Third, by imposing consequences for unaesthetic behaviour, aestheticism ensured the Heian aristocracy was homogenous, that is, that members of the Heian aristocracy all spoke, behaved and interacted in a particular manner. By homogenising aristocratic society, aestheticism also closed and defined aristocratic society. Aestheticism identified aristocrats and separated them from commoners; it ensured there was no confusing the two communities. The affair, then, that adhered to aesthetic convention was legitimate, and while the affair that did not was not criminal in the legal sense, it was, like Kashiwagi's dealings with Onna San no Miya, distasteful, shameful and potentially disgraceful. Acceptance, even prestige, came through avoiding such behaviour.

\section{The Unaesthetic Aesthetic Affair}

Even when conducted within aesthetic parameters, affairs were not always the things of beauty they ideally should have been. Like marriage, affairs had the potential to bring great dissatisfaction to the parties involved. In 'When a Court Lady is on Leave', Shōnagon describes how uncomfortable it is for a woman to receive a man when on leave from court. ${ }^{72}$ If her lover arrives, a woman feels obliged to let him in, but they can have no peace, for the owner of the house and his servants make the situation uncomfortable. Even when at the palace and in familiar surroundings with familiar company, receiving a lover could be difficult. In her list of 'Hateful Things', Shōnagon includes: 'An admirer has come on a clandestine visit, but a dog catches sight of him and starts barking. One feels like killing the beast. One has been foolish enough to invite a man to spend the

72 Ibid., pp. 182-184. 
night in an unsuitable place - and then he starts snoring. ${ }^{37}$ In both of these cases, the 'hateful thing' is the risk of discovery. Fear of exposure surely decreased the enjoyment of affairs for some.

Waiting for a lover could be just as uncomfortable as receiving a lover, especially when the waiting proved in vain. Shōnagon, in her list of 'Depressing Things', includes:

It is quite late at night and a woman has been expecting a visitor. Hearing finally the stealthy tapping, she sends her maid to open the gate and lies waiting excitedly. But the name announced by the maid is that of someone with whom she has absolutely no connection. Of all the depressing things this is by far the worst. ${ }^{74}$

The Mother of Michitsuna similarly waits, night after night, for Kaneie but, night after night, he fails to show. She, better than anybody, describes just how 'depressing' such an experience was. The Mother of Michitsuna, however, may have expected too much from Kaneie, given her rank in relation to his. Though she is recorded as one of the three great beauties of her day, the Mother of Michitsuna was not of sufficient rank to deserve Kaneie's constant attention. ${ }^{75}$ A man, like Kaneie, with many lovers, necessarily had to neglect some in order to please others. ${ }^{76}$ The mark of a good lover, then, was his ability to treat all his women as they deserved, with regard to their rank and their birth, and without partiality or discrimination. ${ }^{77}$

The matter of depression (a term not to be interpreted pathologically) is a curious one, for Heian aestheticism encouraged depression or, more accurately, a delicate pathos and appreciation of the transience of life and the world. The world, to the Heian aristocrat, was viewed as a place of suffering; it was not a place of happiness. Because affairs and aestheticism were inseparable, it follows that if aestheticism was characterised by a melancholic nature, then so too were affairs. Affairs, as a form of aesthetic expression, exhibited the nature of Heian aestheticism:

Expressing depression was also an aesthetic convention, for it was a way of demonstrating sensitivity. Upon parting, for example, lovers frequently expressed their grief at the prospect of separation or solitude. Also, an exchange of poems between the Mother of Michitsuna and Kaneie's sister, Lady Jōganden, reads like a competition over who is suffering the most from their relationship. ${ }^{78}$

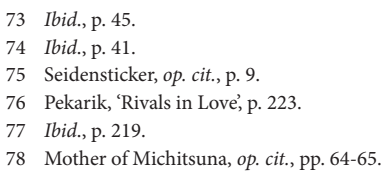


Seidensticker, in his introduction to The Gossamer Years, attributes the intensity of female suffering to Heian marriage institutions and the constitution of the Heian lady: 'the uncertainty of a badly articulated system of polygamy must have been intense. The insanity of Higekuro's wife in the Tale of Genji and the hysterical jealousy of Michitsuna's mother were perhaps common manifestations of the strain on the mind of the delicate Heian lady. ${ }^{39}$ Jealousy, epitomised in the Mother of Michitsuna, is mentioned by several Heian scholars. Tonomura, for example, suggests that jealousy in the Konjaku collection, 'is strictly a feminine attribute; the term is never used in respect to men, and there are no tales that explicitly discuss male jealousy, although male jealousy is illustrated at work. ${ }^{\prime 0}$ Men were freed from jealousy for they could have whomever they pleased; women, though, were prone to jealousy for they were not afforded the power over sexual relations that men were. Jealousy and anxiety, then, are inseparable, for if ever one woman was jealous of another, she was certainly also anxious that her lover would not permanently replace her with a rival. Morris describes the Heian woman as occupying a precarious position, uncertain of her lover's affection, uncertain of her own future and fearful of rumours and abandonment. ${ }^{81}$ According to Morris, dependence on men and a desire for security produced tension in the Heian woman and made it difficult for her to deal with complications resulting from the polygamous system. ${ }^{82}$

Morris's approach to the psychology of the Heian noblewoman resembles the Annalistes approach to emotions. Annalistes see emotional trauma as resulting from mental and physical insecurity. ${ }^{83}$ More recently, it has been suggested the historian must look to a society's rules of conduct to better understand expressions of emotion within that society. Societies determine what are and are not appropriate forms of emotional expression, thus determining how people within that society react. ${ }^{84}$ Barbara Rosenwein, who has reviewed the approaches to emotions in history, suggests the historian must uncover, among other things, how a community expects emotions to be displayed and how a community evaluates the emotions of other communities. ${ }^{85}$ She further suggests that people move between communities and adjust their emotional responses accordingly. ${ }^{86}$

By adopting Rosenwein's approach, the jealousy and hysteria expressed by Heian women changes from a reaction to insecurity, as Morris and Annalistes might suggest, to a socially sanctioned act. The extent, then, to which Heian women reacted to their

\footnotetext{
79 Seidensticker, op. cit., p. 19.

80 Tonomura, op. cit., p. 138

81 Morris, op. cit., pp. 240-241.

82 Ibid., pp. 243-244.

83 Rosenwein, 'Worrying About Emotions', p. 831-832.

84 Ibid., p. 837.

85 Ibid., p. 842

86 Ibid.
} 
position may not reflect the extent of their insecurity and inner turmoil, but the liberality of their community when it came to expressing emotion. The Mother of Michitsuna, then, expresses her jealousy and disappointment so effusively not because her situation is drastically worse than that of any other woman in Heian Japan, but because her community perceives such effusiveness to be an appropriate mode of emotional expression.

\section{Conclusion}

In Heian-period Japan, relationships between men and women, which Shōnagon ambiguously describes as near but distant, most frequently took the form of extramarital affairs. The unquestioned existence and sheer prevalence of affairs in the Heian period was supported by the nature of the marriage institutions, by perceptions of sexuality, by Shinto and Buddhism, and by aestheticism. The marriage institutions, and the living arrangements involved, facilitated a physical and emotional distance between husbands and wives. Matrimony did not foster loving relationships, therefore people sought love outside marriage. Marriage was also less of an aesthetic outlet than affairs.

Affairs were facilitated by men's sexual freedom. Men were perceived to have natural desires they could not resist, while women were perceived to be naturally desirable and irresistible. Both men and women were expected to engage in affairs; the sexually inactive person could be accused of being unhuman. Such an outlook not only encouraged affairs but, importantly, justified them, even when their nature was akin to rape. Heian religion further encouraged and justified affairs. Shinto saw sex as a positive act, while Buddhism, in viewing all sexual acts as products of desire and hindrances to Buddhahood, rendered affairs as valid as matrimonial relations.

Aristocrats embraced and perpetuated affairs because affairs were aesthetic acts and the aristocracy had a penchant for aestheticism. Affairs were at once products and continuers of aestheticism. While, then, aestheticism informs our understanding of affairs, affairs also inform our understanding of aestheticism. I observe aestheticism acting in three ways in the Heian period. Aestheticism set parameters for behaviour; affairs that fell outside these parameters had a negative character. Bad behaviour led to gossip and mockery, therefore aestheticism set penalties for transgressors. By setting parameters and imposing penalties, aestheticism also homogenised the Heian aristocracy. Even the affair that existed within aesthetic parameters, however, was not always a source of enjoyment. Affairs, being aesthetic acts, bore the general nature of Heian aestheticism, which was largely melancholic. The expression of depression, though, while potentially genuine, was also a way of demonstrating pathos and an accepted emotional outlet in Heian-period Japan. 
New Voices Volume 3

\section{References}

Dalby, L., Kimono: Fashioning Culture (London: Vintage, 2001).

Goodwin, J. R., Selling Songs and Smiles: the Sex Trade in Heian and Kamakura Japan (Honolulu: University of Hawaii Press, 2007).

Hurst, G. C., III. 'Kugyō and Zuryō: Center and Periphery in the Era of Fujiwara no Michinaga', in Adolphson, M., Kamens, E. and Matsumoto S. (eds.), Heian Japan, Centers and Peripheries (Honolulu: University of Hawaii Press, 2007), pp. 66-101.

McCullough, W. H., 'Japanese Marriage Institutions in the Heian Period', Harvard Journal of Asiatic Studies, vol. 27 (1967), pp. 103-167.

McCullough, W. H., 'The Capital and its Society', in Shively, D. H. and McCullough, W. H. (eds.), The Cambridge History of Japan, Volume 2, Heian Japan (Cambridge: Cambridge University Press, 1999), pp. 97-182.

Morris, I., The World of the Shining Prince: Court Life in Ancient Japan (New York: Kodansha America, 1994).

Mother of Michitsuna, The Gossamer Years: The Diary of a Noblewoman of Heian Japan, Seidensticker, E. (trans.) (Tokyo: Tuttle Publishing, 1964).

Murasaki Shikibu, The Diary of Lady Murasaki, Bowring, R. (trans.) (London: Penguin Books, 2005).

Murasaki Shikibu, The Tale of Genji, Tyler, R. (trans.) (New York: Penguin Books, 2003).

Nijō, Lady, The Confessions of Lady Nijō, Brazell, K. (trans.) (Stanford: Stanford University Press, 1973).

Pandey, R., 'Poetry, Sex and Salvation: The "Courtesan" and the Noblewoman in Medieval Japanese Narratives', Japanese Studies, vol. 24, no. 1 (2004), pp. 61-79.

Pekarik, A., 'Rivals in Love', in Pekarik, A. (ed.), Ukifune: Love in The Tale of Genji (New York: Columbia University Press, 1982), pp. 217-230.

Rosenwein, B. H., 'Worrying About Emotions in History', The American Historical Review, vol. 107, no. 3 (2002), pp. 821-845.

Sanae, F. and Watanabe, T., 'From Female Sovereign to Mother of the Nation: Women and Government in the Heian Period', in Adolphson, M., Kamens, E., and Matsumoto, S. (eds.), Heian Japan, Centers and Peripheries (Honolulu: University of Hawaii Press, 2007), pp. 15-34.

Sansom, G., A History of Japan to 1334 (Stanford: Stanford University Press, 1967).

Sei Shōnagon, The Pillow Book of Sei Shōnagon, Morris, I. (trans.) (London: Penguin Books, 1971).

Shirane, H., 'The Uji Chapters and the Denial of the Romance', in Pekarik, A. (ed.), Ukifune: Love in The Tale of Genji (New York: Columbia University Press, 1982), pp. 113-138.

Tonomura, H., 'Black Hair and Red Trousers: Gendering the Flesh in Medieval Japan', The American Historical Review, vol. 99, no. 1 (1994), pp. 129-154.

Varley, P., Japanese Culture, $4^{\text {th }}$ ed. (Honolulu: University of Hawaii Press, 2000).

Walshe, M. O’C., Buddhism and Sex (Kandy: Buddhist Publication Society, 1975). 